\title{
PREVOD KAO MJESTO KONTAKTA I JEZIČKE PROMJENE: MOGUĆNOSTI INTERDISCIPLINARNOG PRISTUPA TRADUKTOLOŠKIM ISTRAŽIVANJIMA
}

Cilj ovog priloga je da ukratko prikaže teorijski uvod i terminološka određenja koja su neophodna za istraživanje** jezičkih promjena pod kontaktom. Naime, prvo je bilo potrebno odredili širi teorijski okvir posmatrajući traduktološke, kontaktološke i sociolingvističke aspekte istraživanja prevođenja i jezičkih promjena uopšte, a zatim uži teorijski okvir koji se bavio samo prevodom kao mjestom kontakta i jezičkim promjenama pod kontaktom.

Ključne riječi: jezički kontakt i uticaj, prevod kao mjesto kontakta, jezičke promjene pod uticajem prevoda

\section{Uvod}

U današnje vrijeme nije teško uočiti razne promjene koje jezik trpi pod uticajem globalizacije i sve šire upotrebe engleskog jezika, što se očituje i u prevodima. Osim u ponašanju govornih zajednica, mjesto gdje nastaje najviše promjena podrazumijeva prenesenu (multimedijalno) i posebno štampanu riječ. Naime, engleski jezik prodire kroz popularnu kulturu, muziku i naravno književnost, tj. prevode romana, bestselera, i ono što ćemo primijetiti u ovoj studiji, kroz veliki broj knjiga iz oblasti popularne psihologije. Mno-

\footnotetext{
* $\quad$ jelena.simunovic@unimediteran.net

** Ovaj rad predstavlja komprimiran i prerađen dio teorijskih razmatranja iz neobjavljene doktorske disertacije autorke pod nazivom „Prevod kao mjesto kontakta i jezičke promjene na primjeru prevoda knjiga popularne psihologije".
} 
gi lingvisti ističu posljedice ovakvog uticaja (Kristal 2003, kod nas Prćić 2011), međutim moguće jezičke promjene, uzroci i razlozi pojava koje kao njegova posljedica nastaju nijesu podrobno istraženi. Ovim pitanjem se prije svega bavi lingvistička kontaktologija, a ukoliko posmatramo prevod kao mjesto kontakta, onda i traduktologija. Pored toga, fenomeni jezičkog kontakta zahtijevaju jedan sociolingvistički pristup, a u našem istraživanju ujedno i kritički pristup, posebno kada su u pitanju ideološki aspekti jezičkih promjena koje proističu iz ovakvih i sličnih prevoda ali i kulturnih i društvenih uticaja. Sve ovo čini neophodnim najšire shvaćen interdisciplinaran pristup navedenom fenomenu.

Kako navodi Ajduković (2004: 74), lingvistička kontaktologija se bavi „zajedno ekstralingvističkim odnosno sociološkim faktorima međujezičkog uticaja i lingvističkim procesima jezičkog kontakta“, a predmet proučavanja su joj svi oblici interferencije. Baveći se na jedan podrobniji način upravo interferencijom i međujezičkim uticajima, kao i procesima unutar jezičkog kontakta tokom samog čina prevođenja možemo doći do bitnih zaključaka o prevodu kao mjestu kontakta kao i o novonastalim jezičkim promjenama.

Rudolf Filipović (1986) jezičke dodire i kontakt dijeli na neposredni (prije svega kontakt govornika i onaj koji kao formu podrazumijeva govor) i posredni (onaj koji uključuje rane medije komunikacije tj. tekst, odnosno prevod), tako se istraživanja jezičkog kontakta koncentrišu ili na izučavanje jezika iseljenika (Filipović 1986) i tzv. preključivanje kodova ili na aspekte jezičkog pozajmljivanja i adaptaciju pozajmljenica (kako u svom pregledu ovih istraživanja navodi Ajduković 2012). Na ovaj način su istraživani mehanizmi i rezultati jezičkog kontakta, ali ne i uzroci nastajanja zanimljivih i novonastalih modela izražavanja koji proističu iz pogrešno ili pravilno adaptiranih govornih tj. pismenih izražajnih mogućnosti i sredstava. Uzimajući u obzir potrebu interdisciplinarnog pristupa problemu i uključivanje uticaja društvenih faktora (kojima se u okvirima istorijske lingvistike naročito bave Tomason i Kaufman (Thomason i Kaufman 1988) u širem smislu ćemo se osvrnuti na jezičke promjene pod kontaktom a zatim i pojmom jezičkih promjena nastalih pod uticajem prevoda (engl. translation-induced 
language change) (Beher, Haus i Kranih 2009; Kranih, Beher i Heder 2011). U ova teorijska razmatranja upustili smo se sa ciljem daljih istraživanja kontaktoloških pojava, kao i lingvističkih i sociolingvističkih faktora koji utiču na njih.

Prevod kao mjesto kontakta dva jezika, dva leksička i sintaksička sistema, ali i dvije kulture i ideologije, često je opisivan u okviru lingvističke kontaktologije, čiji su pioniri Haugen (1988) i Vajnrajh (Weinreich 1968), na našim prostorima prevashodno Filipović (1986) i Ajduković (2004).

\section{Teorijski okvir i terminološka određenja}

Kako bismo uopšte istražili prevod kao mjesto kontakta neophodno je početi od šireg teorijsko-metodološkog okvira koji podrazumijeva sagledavanja glavnih termina iz tri suštinske oblasti koje su u ovom pogledu od značaja, odnosno osvrnuti se na traduktološke, kontaktološke i sociolingvističke aspekte i njihovu moguću međusobnu povezanost.

Jedan od prvih mislilaca u traduktologiji koji se bavi jezičkim uticajima, Džordž Štajner (Steiner 1975: 23), putem primjera iz najvažnijih književnih djela pokazuje da su pojedini jezici u većoj mjeri imali uticaj na našu realnost. Pored svojih filozofskih pogleda na sam jezik, Štajner predviđa lingvističke tokove vezane za naša istraživačka pitanja: „Tekst je umetnut u posebnom istorijskom momentu; sadrži ono što lingvisti nazivaju dijahronijskom strukturom ${ }^{\text {“1 }}$ (1975: 24). Štajner u izvjesnom smislu tvrdi da nam tekst prenosi i namjeru govora, pa su ove postavke od suštinske važnosti za način na koji posmatramo originalne tekstove i prevode. Namjere teksta, kao i slika koju stvara istorijski momenat u kome nalazimo tekst doprinose razotkrivanju uticaja prevoda uopšte. Pored toga, od velikog je značaja način na koji je ovaj autor zainteresovan za pojam interpretacije: „'Interpretacija' kao ono što daje jeziku život izvan

1 "A text is embeded in a specific historical time; it has what linguists call a diachronic structure" (Štajner 1975: 24, naš prevod). U daljem tekstu će su svi prevodi sa engleskog jezika biti naši, osim ukoliko ne navodimo suprotno. 
momenta i mjesta trenutne izjave ili transkripcije, jeste ono čime se bavim“2 (1975: 27). U svojim zaključcima o prevođenju Steiner kritikuje stavove koji prevod čine iskrivljenim i osiromašenim, naglašavajući da istorija često nema materijalnu realnost van jezika. Ono što on suštinski tvrdi je da i književnost i umjetnost prolaze kroz jednu vrstu unutrašnjeg prevoda i da se civilizacija tako čuva i širi. Prema tome, on gleda na jezik kao na jednu cjelinu kako bi iznio svoje stavove o prevođenju i poetici. Iako u okvirima ove studije ne možemo da se u tako širokom smislu bavimo jezikom, smatramo da će jedno iscrpno proučavanje i povezivanje prevoda, jezičkih kontakata i posebnih jezičkih pojava koji nastaju kroz ove činove, dati jedan mali doprinos istraživanjima jezika i prevoda.

Razmatrajući različite definicije prevođenja, važno je pomenuti tri stanovišta: lingvističko, funkcionalno i komunikacijsko. Prije svega, imajući u vidu da one ne pretenduju na sveobuhvatnost, ogradili smo se riječju stanovišta, jer se radi o parcijalnim definicijama i pristupima prevođenju, a kako jedni proizilaze iz drugih (Ivir 1985: 35), ovdje navodimo samo neke. S obzirom na to da svaka od definicija daje svoj doprinos teoriji prevođenja, nećemo se baviti samo jednom, već ćemo pokušati da ih na izvjestan način sistematizujemo, proučavajući svako od ovih stanovišta. Međutim, smatramo da je bit prevođenja upravo u komunikaciji i da je za definisanje prevoda ključna riječ promjena, pa se zastupnici kako lingvističke tako i komunikacijske koncepcije koriste terminima vezanim za jezik kao osnovno sredstvo komunikacije (Ketford 1965, Najda 1964). U okvirima lingvističkog stanovišta, prevođenje se ne povezuje neminovno s vanjezičkim elementima, ali zato potanko proučava gramatičke i leksičke nivoe teksta i jezička pomjeranja i promjene, te je stoga bitno za definisanje prevođenja, kao i prevoda kao mjesta kontakta. Upravo radi fokusa na gramatičke i leksičke aspekte, navodimo definiciju prevoda Džona Ketforda (1967), po kome je prevod „zamena tekstovnog materijala na jednom jeziku (IJ) ekvivalentim tekstovnim materijalom na drugom jeziku (JP)“ (cit. prema Sibinović

2 "Interpretation' as that which gives language life beyond the moment and place of immediate utterance or transcription, is what I am concerned with." (Štajner 1975: 27). 
1979: 96). U svrhe ovog istraživanja za nas je ključna riječ zamjena, jer u samom procesu prevođenja mora doći do nje, a samim tim i do drugih promjena koje se mogu precizirati na osnovu ovog lingvističkog pristupa. Osim što se oslanja na jednu opštu lingvističku teoriju prema kojoj jezik posmatra kao niz obrazaca (engl. patterns), Džon Ketford navodi osnovne lingvističke kategorije, među kojima strukturu definiše kao raspored elemenata (Ketford 1965: 5-6). Treće, funkcionalno stanovište, fokusira se na tekstualne tipologije kao i na posmatranje funkcije koju jezik prije svega ima kao sredstvo prenošenja informacija ${ }^{3}$. Za ovo stanovište je karakteristično da odstupa od strogo lingvističkih okvira, pa Katerina Rajs u tom kontekstu definiše dominantni tip teksta, uključujući i operativni, tj. tekst koji ubjeđuje i poziva na djelovanje. Samim tim je neophodno da se isti vanjezički kriterijumi primijene u prevodu: „[...]u prevodu se mora očuvati jasan poziv na djelovanje od strane slušaoca ili čitaoca“" (Rajs 2000: 27). Ovo stanovište je povezano i sa kritikom i procjenom prevoda. Naime, spominjući jeftine knjige i popularizovanu literaturu, Rajsova zastupa stav da ukoliko se pisac nije potrudio da lijepo uobliči knjigu ni prevodilac nije dužan da se time opterećuje (Rajs 2000: 26). Ipak, pitamo se da li se u tom slučaju efekat koji prenosi pisac može prenijeti iz jednog u drugi jezik.

U svakom slučaju, tipologija Katerine Rajs imala je poseban uticaj na teoriju prevođenja i usmjerila istraživanja ka pragmatičkoj analizi teksta (prema Venuti 2000: 149). Na ovakav karakter analize Rajsove ukazuje Venuti (2000: 149): „[...] prevodilac se ne bavi prosto analizom lingvističkih i kulturoloških odlika stranog teksta, već ih ponovo prenosi, u skladu sa vrijednostima drugačijeg jezika i kulture. ${ }^{5}$ Mnoge rasprave povodom prevođenja kao i kontakata jezika i kultura vode se radi usklađivanja vrijednosti dva jezika i dvije kulture, pa je to jedan od ciljeva sagledavanja prevođenja ali i prevoda i jezičkog kontakta u širem smislu.

\footnotetext{
3 Za dalje informacije v. Rajs K. (2000).

4 "[...] the translation must preserve clear appeal for action on the part of hearer or reader" (Rajs 2000: 27).

5 “[...] translator doesn't simply analyze the linguistic and cultural features of the foreign text, but reverbalizes them according to values of a different language and culture" (Venuti 2000: 149).
} 
Kada je u pitanju komunikacijska definicija prevođenja, predstavnik ovog stanovišta Najda smatra da prevođenje predstavlja „nalaženje najbližeg prirodnog ekvivalenta u jeziku cilju za obavijest izraženu u izvornom jeziku“ (cit. prema Ivir 1985: 36). Komentarišući ovu definiciju, Vladimir Ivir tvrdi „izraz te obavijesti u izvornom jeziku je prirodan, pa takav mora i biti u jeziku-cilju“ (1985: 37). Možda upravo odavde potiču mnogi problemi u objašnjavanju šta predstavlja ispravan prevod i u pogledu donošnja konkretnog suda o tome šta je u jednom jeziku prirodno. Posmatranjem prevoda kao mjesta kontakta svakako se doprinosi uočavanju onog što je prirodno, kako u izvornom tako i u ciljnom jeziku. Stoga komunikacijska definicija prevođenja otvara s jedne strane mnoge načine interpretacije prevoda, a s druge strane ograničava prevod i usmjerava ga ka jednoj prirodnoj, ali i usklađenoj komunikaciji jezika i kultura.

Međutim, i lingvistička definicija posmatra jezik kao komunikaciju; u okvirima funkcionalnog pristupa prevođenju Rajsova tvrdi da se komunikacija postiže na nivou teksta i u odnosu na tip teksta (prema Mandej 2005: 73). Imajući u vidu iznesene stavove, važno je sistematizovati ove pristupe i jasno definisati ono što se prevodom pokušava saopštiti.

U pogledu traduktološkog aspekta, moramo se podsjetiti da se u okviru traduktologije takođe ističe sâm proces prevođenja, o čemu na svoj način pišu i oni koji se bave poetikom prevođenja. U tom smislu, od velikog značaja za istraživanje procesa prevođenja jeste knjiga Umberta Eka, Otprilike isto:iskustva prevođenja (2006). U ovom djelu, Eko nas vodi kroz sopstvena iskustva i otkrivajući kako mu polazi za rukom da se sam pomiri sa prevodom svojih djela, kontekstualno razriješi probleme, uvede čitaoce u svijet jednog pisca i prevodioca, a detaljno govori i o uticajima prevoda u stranoj kulturi. Eko prije svega naglašava uticaj konteksta, dajući primjere mašinskih prevoda i analizirajući ih kako bi postigao jednu vrstu kontekstualnog razrješavanja, kao i naglasio uticaj vanjezičkog konteksta, koji naziva informacijom o svijetu (2006: 29-31). Pošto prevođenje posmatra na nivou tekstova, a ne sistema, on odbacuje mogućnost nametanja nekog drugog viđenja svijeta kroz prevod (2006: 35). 
Prevodilac mora da ima pretpostavku o mogućem svijetu koji tekst predstavlja, a za Umberta Eka to znači da će prevodilac izabrati rješenje koje najviše odgovara datoj situaciji i kontekstu (2006: 42, 43). Ovdje treba primijetiti da Eko polazi od stanovišta da je taj svijet neodređen prije nego prevodilac sagleda sve što mu je na raspolaganju kako bi došao do rješenja koja će prevod potom odrediti i neminovno ograničiti. U ovom smislu, prevod predstavlja kontakt dva svijeta prilikom kojeg svaki traži svoje uporište, tj. prikazuje se u svjetlu sopstvenih izražajnih sredstava, a na prevodiocu je da nas iz jednoga takoreći „prevede“ u drugi, bez gubitka onoga što je suštinska i zajednička realnost oba svijeta, ali se izražava na dva različita jezika.

Prije nego što zaključimo ovaj opis traduktoloških aspekata rada, osvrnućemo se na još jedno novije istraživanje. Naime, želimo da pomenemo skoro izdati udžbenik Ane A. Jovanović (2015) u kome daje osnove teorije prevođenja, ali se bavi i kritičkim poređenjem prevodâ, kao i retradukcijom, potrebama i uzrocima koji vode do nje. Jovanovićeva navodi definicije prevođenja koje uključuju faktore od kojih zavisi ekvivalencija, ističe pojam i mehanizam promjenljivosti kao i kompenzacioni mehanizam u prevođenju. Ona se bavi istraživanjima raznih naučnika (kako francuskih tako i kanadskih) koji u oblast traduktologije uvode pojmove promjenjivosti i stoga zaključuje: „Najpre, i na jednoj i na drugoj strani ključan je, po našem mišljenju, koncept varijabilnosti - drugim rečima promenljivosti, pomičnosti, pokretljivosti“" (Jovanović 2015: 28). Sve ovo navodi u cilju ukazivanja da u procesu prevođenja postoje dvije ose, horizontalna (leksičko, sintaksičko i tekstualno ulančavanje komponenti izvornog jezika) i vertikalna (gradiranje komponenti na semantičkom, gramatičkom i stilskom nivou) i ,[...] stalno varirajuća skala uticaja mnogobrojnih faktora" (2015: 29). Iako nije lak zadatak pratiti razne promjene u jeziku tokom procesa prevođenja, ova autorka nas upućuje u smjeru sistemskog praćenja tih promjena, uočavajući da se mijenja ono što predstavlja nestabilni pojam ekvivalncije, ono što se uzima kao prevodna jedinica, kao i ravnotežu tehnika i modela pri samom prevođenju.

Kao što je u traduktologiji analizirano, prevođenje stranih kulturnih elemenata predstavlja zapravo jezički kontakt i kontakt dvije 
kulture, odnosno, u širem smislu, kontakt dvije jezičke (nacionalne, etničke itd.) zajednice i susret njihovog „pogleda na svet“, uključujući i tradiciju, baštinu, način razmišljanja.

Ono čime kontaktna lingvistika doprinosi svojom povezanošću sa prevodom i sociolingvističkim pristupom, kao i ono što nam novija kontaktološka istraživanja pružaju kada je u pitanju prevod kao mjesto kontakta, najviše se oslanja na nasleđe onih koji su prvi opisali prirodu jezičkog kontakta. Naime, prema mišljenju Vajnrajha (1968: 1) dva jezika su u kontaktu onda kada ih isti govornici naizmjenično upotrebljavaju (bilingvizam). On takođe smatra da društveni faktori podstiču ili sprečavaju interferenciju (1968: 5). Imajući to u vidu, želimo da naglasimo kako do te naizmjenične upotrebe dolazi i prilikom procesa prevođenja, naravno na jedan indirektniji način. Interesantno je da ovaj autor, osim što povezuje bilingvizam sa jezičkim kontaktom, definiše interferenciju ${ }^{6}$ kao bilo koje odstupanje od jezičke norme u govoru, nazivajući je rezultatom kontakta i spominjući pritom uticaj na norme jezikâ koji su u kontaktu (1968: 1). Smatramo da se njegovo šire shvatanje ovog pojma može primijeniti i na prevod kao mjesto kontakta, kao i da možemo govoriti o sličnim međujezičkim uticajima. Vajnrajh takođe na samom početku svog istraživanja s jezičkim kontaktom dovodi u vezu i društvene faktore koji utiču na kontakt, kao i kulturološki kontakt.

Njegove zaključke interpretiraju i savremeni kontaktolozi. Naime, u Uvodu u leksičku kontaktologiju Jovan Ajduković daje niz definicija jezičkog kontakta ${ }^{7}$ i navodi da je prema Vajnhrajhu bilingvizam neizostavan dio jezičkog kontakta, a citira Munena (1987) koji prevod naziva istovremeno jezičkim kontaktom i bilingvalnom pojavom (prema Ajduković 2004: 8). Štaviše, kako Ajduković navo-

$6 \quad$ Moramo napomenuti da je interferencija relativno sporan termin u kontaktnoj lingvistici, jer ga različiti istraživači na različite načine interpretiraju. Odlučili smo se da citiramo upravo ovu definiciju jer je jedna od sveobuhvatnijih. Nešto uži termin je transferencija (M. Klajn), ali se ona odnosi na konkretno prenošenje elemenata iz stranog jezika. U translatologiji se interferencija takođe odnosi na uticaj jednog jezika na drugi.

7 Između ostalih navodi definiciju O.V. Opeljbauma prema kome „jezički kontakti predstavljaju bilo koju vrstu međujezičkih veza u bilingalnoj situaciji“ ( naglasak Ajduković 2004: 9). 
di: „Mesto jezičkog kontakta predstavlja bilingvalni i monolingvalni govornik" (2004: 15). Prema tome, prevod bi se na ovaj način morao sagledati u okvirima kontaktne lingvistike, a činjenica da se radi o bilingvalnoj pojavi koja utiče i na monolingvalne čitaoce predstavlja osnovu za proučavanje njegovih uticaja i međujezičkih uticaja koji nastaju kroz proces prevođenja i recepcije prevoda. Posvetivši mnogo pažnje adaptaciji pozajmljenica, Ajduković (2004: 19) navodi da je pisani tekst svojevrsni informator. Značajan ekstralingvistički faktor u proučavanju jezičkih kontakata, kako navodi Vajnrajh (prema Ajduković 2004: 20), jeste „[...] odnos [bilingvalnog govornika] prema svakom od jezika“. Kako je u procesu prevođenja bilingvalni govornik prevodilac, kada proučavamo međujezičke uticaje moramo uključiti i njega, tj. ovdje prevod kao proizvod njegovog rada, ali takođe i proširiti uticaje na monolingvalnog govornika koji čita prevod.

Jezički kontakt nas takođe upućuje na sociolingvistiku kao još jednu od disciplina koja ga neminovno proučava. Kako tvrde Apel i Mujsken „[...] proučavanje jezičkog kontakta se razvilo u paradigmu

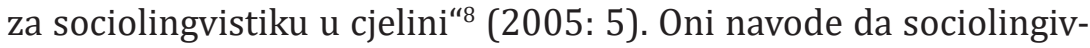
stika i kontaktna lingvistika proučavaju ista pitanja (promjenu stila, lingvističke promjene i sl.) u širem smislu, kao i da su društveni i kulturni faktori uticali na razvoj ove oblasti. Pored pet situacija kontakta koje navode, a koje uključuju migracije ljudi, oni ističu i tzv. migraciju jezika, koja se ne dešava više samo migracijom ljudi već prenošenjem jezika kroz medije, književnost, umjetnost i slično. Iako ne predviđaju buduće jezičke promjene, Apel i Mujsken pominju protekle periode (između ostalog i to i do kakvih je sve lingvističkih promjena došlo prisustvom Rimljana i Mongola kao i uticaja raznih jezika na Balkanu), zaključujući: „Trenutna stabilnost je rezultat kretanja u prošlosti“9 (2005: 6). Ukoliko bismo se usudili da proširimo ovaj zaključak, vjerujemo da se trajne i dijahronijske promjene u srpskom jeziku ne dešavaju olako, imajući u

8 " $[. .$.$] the study of language contact has developed into a paradigm for$ sociolinguistics as a whole" (Apel i Mujsken 2005: 5).

9 "Present stability is the result of movement in the past" (Apel \& Mujsken 2005: 6). 
vidu npr. petsto godina pod turskom okupacijom, što nas navodi na razmišljanje o intenzitetu kako prošlih tako i sadašnjih kontakata (npr. srpskog i trenutno najaktuelnijeg engleskog jezika).

Još jedan veliki doprinos studije Apela i Mujskena jeste u tome što ona ističe nesigurne osnove izučavanja jezičkog kontakta i jezičkih promjena i ograničava ga na različite jezičke situacije (2005: 154). Među njima se navode kulturni uticaj i leksička pozajmljivanja, kao i naročito važan pojam imitiranja prestižnih jezičkih obrazaca (engl. imitation of prestige patterns). Oni za ove pojave daju primjere iz različitih jezika, ali kada je u pitanju donošenje konkretnog zaključka, ograničavaju se na to da sintaktičko pozajmljivanje takođe može da bude motivisano dešavanjima unutar jednog jezika. Ipak, zabilježene primjere promjena u jezicima pripisuju i imitaciji prestižnih jezičkih obrazaca (Apel i Mujsken 2005: 162). Upravo zbog ovih podijeljenih mišljenja povodom onoga šta jezička promjena predstavlja, sagledaćemo je, osim u svjetlu kontaktoloških istraživanja, i u okvirima sociolingvističkih istraživanja.

Još jedan autor koji uporedo definiše jezički kontakt i jezičke promjene jeste Jaron Matras (2009) koji, stavljajući u centar bilingvalnog govornika, ističe komunikaciju i slušanje jezika. Njegov integrativni funkcionalni model ističe ulogu konstrukcije kao pojedinačne jezičke strukture, i kreativnost govornika i jezičku promjenu naziva proizvodom inovacije pojedinaca. Prema njegovom viđenju, imajući u vidu potrebu da se neka poruka u potpunosti prenese, postoji s jedne strane lojalnost spram postojećih normi, a s druge strane težnja da se eksploatiše cijeli repertoar onoga što se može reći, bez obzira na ograničavajuće situacione faktore (Matras 2009: 3-5).

Pored toga, kako Matras (2009) tvrdi, bilingvalni govornik ne može u potpunosti da „zatvori vrata” jednom jeziku kako bi se koristio drugim, pa imajući u vidu da su naši prevodioci bilingvalni govornici, miješanje lingvističkih struktura nam ne smije biti strano, a od prevodioca ne možemo zahtijevati da se ne „ponaša” kao bilingvalni govornik. Štaviše, kako Matras zaključuje: „[...] kontakt ovdje ne posmatramo kao 'spoljašnji' faktor koji započinje promjenu, već kao onaj koji koji se javlja unutar obrade i upotrebe samog jezika u repertoaru lingvističkih struktura multilingvalnog govor- 
nika"10 (Matras 2009: 5). Matras dakle posmatra komunikacionu dimenziju kontakta, pretpostavljajući da su jezičke promjene odraz ove a ne društvene dimenzije kontakta (2009: 6). Njegovi zaključci se stoga lako mogu primijeniti na prevodioca koji prilikom procesa prevođenja vrši obradu jezika i stavlja ga u upotrebu, a sve ovo je dio jednog unutrašnjeg procesa. Kontakt u ovom slučaju tako ne nastaje van prevoda, nego je jedan od faktora koje moramo imati u vidu tokom procesa prevođenja.

Važne impulse u kontekstu naših razmatranja pruža i teorija jezika u kontaktu koju je razvio Rudolf Filipović (1986). Filipović smatra da je bolji način proučavanja jezičkog dodira ili kontakta onaj koji ne podrazumijeva samo lingvističke elemente: „Mnogi izvanlingvistički činioci (extralinguistc factors) mogu vrlo dobro poslužiti da se neki elementi jezičnog dodira protumače ispravnije" (1986: 26). On se poziva na društveno-kulturni kontekst i svoj pristup naziva sociolingvističkim, jer se bavi i sociološkom i lingvističkom analizom. Mjesto kontakta predstavlja bilingvalni govornik, a Filipovića naročito zanima razlučivanje i stapanje dva jezička sistema kod bilingvalnih govornika.

Ono što je novo u njegovoj teoriji jeste podjela na posredno i neposredno posuđivanje i donošenje zaključaka o njihovim rezultatima na osnovu vrste kontakta. Filipović (1986) je takođe ograničio svoju analizu na različite jezičke nivoe, imajući u vidu da se najviše pozajmljuje leksika, i koncentrisao se na analizu adaptacije pozajmljenica. U ovom smislu, opisao je posredno posuđivanje, ograničavajući ga uglavnom na ono leksičko (vršeći analizu na fonološkom, morfološkom i semantičkom nivou), a posredničke medije (u koje ubraja i masovne medije) podijelio je na pisanu i izgovorenu riječ, tvrdeći da: „Ta osnovna osobina posrednog posuđivanja određuje način i opseg istraživanja jezičkih dodira u tom tipu posuđivanja“ (Filipović 1986: 50). Filipović (1986) svakako spominje i prevod kao jednu od perspektiva sagledavanja jezičkog kontakta.

U širem teorijskom okviru moramo se osvrnuti i na neke autore koji su se prevashodno bavili istorijskom lingvistikom i dijahronij-

10 “[...] contact is not regarded here as an 'external' factor that triggers change, but as one that is internal to the processing and use of language itself in the multilingual speaker's repertoire of linguistic structures.” (Matras 2009: 5). 
skim aspektima jezika u kontaktu, ali su dali veliki doprinos i svojim pokušajima da predstave jednu univerzalnu teoriju jezičkih promjena,. Naime, Tomason i Kaufman (1988), ističući socijalni kontekst jezika za svoju knjigu, konstatuju „,...]naša knjiga služi kao doprinos naporima naučnika poput Jurijela Vajnrajha, Viljema Labova i Dela Hajmza, da podsjeti one koji su u lingvističkoj profesiji da su jezici proizvod komunikacije kao i sredstvo komunikacije među ljudima" ${ }^{11}$ (1988: 4). Oni se u društveno-istorijskom kontekstu koncentrišu na obim i rasprostranjenje jezičkih promjena, u nadi da će njihovi zaključci pomoći u posmatranju jezičkih promjena koje se trenutno odvijaju i analiziraju. Iako se u svojoj studiji bave vrstama ograničenja jezičke promjene, oni tvrde: „Kada su u pitanju striktno lingvističke mogućnosti bilo koja lingvistička odlika se može prenijeti iz bilo kog u bilo koji drugi jezik"12 (Tomason i Kaufman 1988: 14). Jedno od ograničenja jezičke promjene koju Hajmz (prema Tomason i Kaufman 1988) naziva načelo prirodnosti, prema mišljenju ovih autora ima važnu ulogu u teoriji jezičke promjene, naročito u kontekstu teorije o univerzalnoj označenosti ili markiranosti jezika: „[...]prirodne promjene proizilaze iz opštih principa, dok ostale promjene nastaju u okolnostima u kojima obično ne očekujemo da se pojave"13 (cit. prema Tomason i Kaufman 1988: 22). Naše okolnosti podrazumijevaju prevod kao mjesto kontakta, a o pojavama koje nastaju u ovim okvirima možemo donositi zaključke na osnovu opšteg načela prirodnosti (kao jednog od kriterijuma otkrivanja jezičke promjene koji smo koristili u analizi).

Takođe, kako su Tomason i Kaufman (1988: 37) podijelili interferenciju na pozajmljivanje i interferenciju kroz zamjenu (kada ne

11 "[...] our book is meant as a contribution to the efforts of such scholars as Uriel Weinreich, William Labov and Dell Hymes to remind the linguistic profession, that languages are a prodact of, and a vehicle for, communication among people." (Tomason i Kaufman 1988: 4).

12 "As far as the strictly linguistic possibilities go, any linguistic feature can be transferred from any language to any other language." (Tomason i Kaufman 1988: 14).

13 " [...] natural changes are produced from general principles, while other changes arise in the circumstances where they would not be expected" (U: Tomason i Kaufman 1988: 22). 
dolazi do održavanja jezika već je krajnji rezultat zamjena jezika) ${ }^{14}$, autori ukazuju na uticaj bilingvizma, i to posebno dugoročni uticaj bilingvizma na intenzivno strukturno pozajmljivanje.

Još jedan opšti zaključak u okviru pozajmljivanja, kako ga vide Tomason i Kaufman, jeste da se u kontaktnoj situaciji prvo pozajmljuje leksika a zatim strukturne odlike (1988: 40), što je bitno uočiti kada sagledamo trendove anglosrpskog, o čemu detaljno piše Tvrtko Prćić (2005), sprovodeći samostalno ili u koautorstvu mnoga istraživanja i projekte o samoj upotrebi anglicizama.

Ipak, interesantno je da su strukturne promjene manje izučavane u okvirima istraživanja jezičkih kontakata i da je često teško utvrditi uzroke njihovog nastajanja. Iako neki lingvisti posmatraju strukture različitih jezika, Tomason i Kaufman (1988) uočavaju da struktura jezika nije lingvistički faktor koji dovodi do jezičke promjene, već se oslanjaju na društvene uticaje koji određuju kakav će biti ishod kontaktne situacije. Ipak, ovi autori ne žele da u potpunosti izopšte lingvističke faktore, koji mogu uticati na neke od kontaktnih situacija. Kada je u pitanju struktura jezika, naš pristup prema proučavanju jezičkih promjena najbolje je opisao upravo Tvrtko Prćić:

„[...] bilo kakva analiza engleskog jezika prema srpskom [...] ne može da zaobiđe činjenicu da ova dva jezika raspolažu različitim, ali uporedivim, pravilima sistema i principima upotrebe, koje je neophodno posmatrati u svetlu svakodnevnih međusobnih kontakata srpskog jezika i kulture s engleskim jezikom i anglofonim kulturama." (2011: 14)

U svojoj knjizi Engleski u srpskom, ovaj autor formira polje kontaktno-kontrastivne lingvistike koja podrazumijeva ,'izučavanje sličnosti i razlika između engleskog i srpskog (ili bilo kojeg drugog) jezika, u kontekstu engleskog kao odomaćenog stranog jezika i njegovih sveukupnih uticaja na srpski (ili bilo koji drugi) jezik'“ (Prćić 2011: 14).

Među društvenim faktorima, Tomason i Kaufman (1988), kao i mnogi drugi ${ }^{15}$, pominju prestiž, kao i autore koji ga navode kao

14 Ova podjela je značajna jer se ovaj tip pozajmljivanja i dalje odnosi na interferenciju, a ne recimo na pojave koje Ajduković (2004) naziva posuđenicama.

15 Filipović (1986: 41); Ajduković (2004: 20); Apel i Mujsken (2006: 162); Hlebec (2009: 19); Kranih i dr. (2011: 14, 16). 
uzrok pozajmljivanja, ali iako ga ne osporavaju u potpunosti, smatraju da to nije iscrpan način sagledavanja pozajmljivanja i interferencije uopšteno (1988: 43-44).

Kako bismo na jedan pregledan način sagledali sociolingvistički pristup, želimo da naglasimo razlike između pristupa jezičkim promjenama koji smo predstavili kroz istraživanja u okvirima istorijske lingvistike i sociolingvistike. Prije svega, kako tvrdi Jelena Filipović: „Istorijsko-lingvistički pristup nudi malo informacija o razlozima za promenu, kao i o načinu na koji se ona dogodila (posebno kada se radi o promenama usled kontakta, pre svega u višejezičnim zajednicama)" (2009: 17). U analizi se trudimo da ukažemo na jezičke promjene nastale usljed kontakta, a koje su rezultat prevoda, tj. svega onoga što proces prevođenja u datom smjeru (englesko-srpski) donosi sa sobom, uključujući i uticaje na jezik budućih generacija. U traduktologiji se smatra da je teško dokazati zašto neki prevod sadrži strane elemente (i u kojoj mjeri treba da ih sadrži), pa bi možda sociolingvistički i kontaktološki pristup mogao biti od pomoći u smislu otkrivanja strategija na osnovu kojih se u procesu prevođenja uzimaju u obzir i društveni i jezički činioci.

Kako smo i ranije naglasili, istorijska lingvistika prati dijahrone jezičke promjene, dok se u sociolingvistici javlja mogućnost posmatranja jezičkih promjena tokom njihovog trajanja (iako bez mogućnosti predviđanja da li će se te promjene ustaliti ili neće). Drugim riječima, kako je to još Labov primijetio, „[...]društveni pritisci stalno djeluju na jezik, ne iz neke daleke tačke u prošlosti, već kao stalno prisutna društvena sila koja djeluje u trenutku sadašnjosti“16 (Labov 1972: 3). Naime, Labov je bio među istraživačima koji su u analizi jezičkih promjena u govornim zajednicama koristili princip prividnog vremena (engl. apparent time) u odnosu na realno vrijeme ${ }^{17}$. Stoga je veoma važno posmatranje mogućih jezičkih promjena u toku njihovog trajanja, kao i samo definisanje jezičke

16 “[...] social pressures are continually operating upon language, not from some remote point in the past, but as an immanent social force acting in the living present." (Labov 1972: 3).

17 Za diskusiju ovih pojmova vidjeti drugo poglavlje sociolingvistike Milroja i Gordona (2003), kao i deveto poglavlje knjige The Social Stratification of English in New York City, Viljema Labova (2006). 
promjene kao moguće (jer ne znamo da li će se te promjene ustaliti, upravo kao i u istraživanjima govornih zajednica).

U smislu povezivanja ovdje predstavljenih teorijskih postulata i pristupa analizi jezičkih promjena u užem smislu, oslonićemo se na jedinstvenu teoriju jezičkih promjena. U svom radu Varijacije unutar padežnih sistema: u različitim tipovima srpskih varijeteta $-U$ prilog jedinstvenoj teoriji jezičkih promena, Jelena Filipović (1999) naglašava osnovnu hipotezu da je priroda svih promjena (u vremenu i prostoru, izazvanih internim ili eksternim činiocima) identična. Prema tome, procesi mijenjanja jezika su nalik onima koji se dešavaju u jednojezičnim zajednicama.

Potreba da jezičke promjene opišemo kako iz dijahronijske, tako i sinhronijske perspektive nastala je iz težnje da ukažemo na činjenicu da je jezik živa materija koja se ne može u potpunosti predvidjeti, ali se njene varijacije mogu posmatrati iz više perspektiva i donijeti zaključci, posebno o uticaju društvenih faktora i trenutnim odnosima moći u jednoj jezičkoj zajednici. Kako Milorad Radovanović zaključuje u svojoj knjizi Fazi lingvistika: „[...] važan deo shvatanja sinhronije (bilo čega, pa i jezika) zasniva se na poznavanju i razumevanju dijahronije (jezika ili bilo čega drugog), uz pretpostavaku da je dijahronija proces neprekinut, te da je bilo koji sinhronijski presek u tom smislu - samo njen deo" (2015: 194). Kako su jezičke promjene inače kompleksan pojam, i kako svakako ni dijahronijske studije ne mogu u potpunosti opisati i zabilježiti cjelokupan proces njihovog nastajanja i širenja, dovoljno je kompleksno pokušati da objasnimo njihov dio.

Međutim, jezički kontakt treba sagledati i sa stanovišta kritičke sociolingvistike, jer tradicionalno tumačenje pojma govorne zajednice, prema kom se ona posmatra izolovano od ostalih, često isključuje mogućnost kontakta između različitih govornih zajednica ${ }^{18}$. Uzimajući u obzir osnovne teorijske postavke iz istorijske lingvistike, kontaktologije i traduktologije, moramo uočiti da ovo istraživanje ne posmatra govornu zajednicu kao izolovanu grupu govornika jednog varijeteta, već se više osvrće na jednu društvenu zajednicu koja jezik po svojim potrebama mijenja, prevodi i oblikuje pod uti-

18 Za pojašnjenje v. Milroj i Gordon (2003: 133,134). 
cajem kako unutrašnjih faktora, tako i spoljašnjih kontakata.

Stoga, ponovnim osvrtom na to kako istorijska lingvistika posmatra jezičke promjene koje su uslovljene kontaktom želimo da još jednom naglasimo rezultate različitih stepena kontakta. Kako to u vidu skale prikazuju Tomason i Kaufman (1988: 37), kao i J. Filipović (2009: 91), leksičko pozajmljivanje je uobičajeno i rezultat je povremenog kontakta dvije društvene zajednice: u jednoj mjeri intenzivniji kontakt može voditi do pojave značajnih strukturnih pozajmljenica, a konačno kontakt koji prati jak društveni pritisak može da dovede i do tipološkog restrukturiranja varijeteta, zamjene, pa i smrti jezika. Kontakt je, prema tome, jedno jezgro svih promjena (unutrašnjih i spoljnih) koje u manjoj ili većoj mjeri utiču na neki jezik, a kako je on neminovan, tako su i jezičke promjene, u jednom širem smislu i jednoj takoreći globalnoj društvenoj zajednici, neminovne.

Imajući u vidu jedan ovakav pristup, definicija jezičkog kontakta mora podrazumijevati postojanje dominantnog jezika i kulture barem u nekim segmentima jezičkog izražavanja pojedine društvene zajednice.

Sam ovaj pojam vodi nas do ključnog termina za ova razmatranja, a to je prevod kao mjesto kontakta. Njega smo definisali oslanjajući se prije svega na teoriju jezika u kontatku kako je uspostavlja R. Filipović (1986). On daje temeljan istorijski pregled kontaktoloških istraživanja ${ }^{19}$ kada su u pitanju glavni predstavnici i iznosi nekoliko važnih zaključaka. Naime, kada se u početku kontaktoloških istraživanja govorilo o miješanim jezicima, Filipović (1986: 21) ističe da je prema Vindišu (Windisch) sopstveni jezik je onaj koji postaje miješani jezik. Citirajući Šuharta (Schuchardt), Filipović navodi tadašnje termine oponašanje i strani uticaji koji su izjednačeni sa terminom miješanje jezika, što je bitno za izbor terminologije, kao i istraživačkih pitanja koji kasnije proističu iz ovakvog stava. Međutim, jedan od glavnih zaključaka jeste da Filipović na osnovu rada svojih prethodnika (posebno Vajnrajha) ističe da je bilingvalni govornik mjesto kontakta (1986: 26, 33). U jednom širem smislu, možemo zaključiti da je mjesto kontakta i ono što bilingvalni go-

19 V. Filipović 1986 (19-31). 
vornik svojim jezičkim ponašanjem proizvede, između ostalog, ili možda čak u prvom redu - prevod.

Filipović takođe opisuje karakteristike bilingvalnog govornika koje se, naravno, mogu primijeniti i na prevodioca, posebno faktor koji naziva motivacijom za upotrebu drugog jezika. Međutim, kako ovaj autor navodi, ovo mogu biti osnovni činioci u procesu interferencije, ali nijesu istraženi u dovoljnoj mjeri kako bismo ih $\mathrm{u}$ potpunosti povezali sa njom (1986 : 27). Na taj način dolazi i do razlikovanja i terminološkog određenja interferencije i integracije. Kako Filipović navodi prema Vajnrajhu interferencija je posljedica kontakta, „Ali čim je jedan element iz jezika A preuzet u jezik B, to više nije interferencija, već integracija (integration) (Filipović 1986 : 30). Pojave koje planiramo da opišemo u budućem istraživanju korpusa imaju dodirnih tačaka sa oba procesa, jer kao što ćemo vidjeti, one su posljedice kontakta, a njihova integracija je možda nepotpuna, ali je upotreba u korpusu očigledna.

Nekoliko decenija posle Filipovića i autor Jovan Ajduković (2004) daje bibliografski pregled sličnih istraživanja koji nam pruža precizan uvid u definicije jezičkog kontakta, a samim tim i prevoda kao mjesta kontakta. Tako njegove definicije jezičkog kontakta - koje podrazumijevaju bilo koju vrstu jezičkih veza u bilingvalnoj situaciji (O.V. Opeljbaum prema Ajduković 2004: 9) - uključuju i čitaoce prevoda knjiga popularne psihologije (koji nijesu nužno bilingvali), pod pretpostavkom da se putem takvih prevoda šire jezički i ideološki uticaji. Ajduković (2004: 9) nas takođe podsjeća na ključna istraživačka pitanja E. Haugena, ${ }^{20}$ među kojima su pitanja odvojenosti dva jezika kao i ono što se dešava kada se govornik prebacuje s jednog koda na drugi. Proces prevođenja mora podrazumijevati oba koraka, a prevodilac je prema ovom teorijskom stanovištu govornik; dakle on je govornik (bilingval) i u momentu operacije prevođenja, uz očiglednu razliku u tome da posljedica njegovog djelovanja nije govor već tekst, odnosno prevod. Stoga prevod mora predstavljati moguću vrstu uzorka kada su u pitanju promjene koje

20 Ovdje nećemo navoditi sva pitanja, jer ona po našem mišljenju predstavljaju ostala ključna pitanja u kontaktologiji poput učenja drugog jezika i sl. (v.Ajduković 2004: 9). 
se u jeziku prevoda dešavaju prilikom kontakta dva jezika. Na ovaj način, kada istražimo i analiziramo prevod, on nam daje sinhronijsku sliku kontaktološke situacije kao i "trenutni snimak“ onoga što se u jeziku primaocu, tj. jeziku prevoda dešava (naravno, uz pretpostavku da se radi o savremenim prevodima ${ }^{21}$ ). Još jedan bitan razlog zbog kojeg posmatramo prevod kao mjesto kontakta jeste upravo kontakt monolingvala sa prevodom, odnosno uticaj prevoda na njihovo jezičko i govorno ponašanje.

\section{Zaključak}

Imajući u vidu gore navedene teorijske postavke zaključujemo da se prevod treba češće i detaljnije sagledavati kroz interdisciplinarni pristup koji takođe uključuje izučavanja prevoda kao mjesta kontakta. Iako se u izučavanjima neposrednih jezičkih kontakata ne bavimo prevodom, ovdje predstavljeni teorijski okvir nas u okvirima posrednih jezičkih kontakata navodi da prvo sagledamo istorijsku sliku izučavanja prevoda, a zatim povežemo različite aspekte prevođenja (traduktološke, kontaktološke i sociolingvističke) kako bi na jedan interdisciplinaran način istraživali prevod kao mjesto kontakta. Poput govornika koji se u kontaktološkim istraživanjima smatraju nepouzdanim, prevodioci takođe predstavljaju kamen spoticanja za bilježenje jezičkih promjena. Međutim, ako se kako traduktologija teži da ukaže bavimo prevodom kao rezultatom jezičke pojave poput čak i suptilnih promjena se mogu lakše pratiti i ispitati. Stoga, smatramo opravdanim naše osnovne teorijske postavke prema kojima prevod predstavlja samo mjesto kontakta.

21 Pitanja potrebe ponovnog prevođenja nekog klasičnog književnog djela i jezičkih promjena koje bi se mogle uočiti prilikom analize diskursa tih prevoda, predstavljaju jednu mogućnost sličnih istraživanja, priznajemo zanimljivih, ali koja neće biti fokus ovog istraživanja. 


\section{LITERATURA}

Ајдуковић 2004: Ајдуковић, Ј. Увод у лексичку контактологију: теорија адаптације русизама, Београд: Фото Футура.

Ајдуковић 2012: Ајдуковић, Ј. Радови из лингвистичке контактологије, Београд: Фото Футура.

Сибиновић 1979: Сибиновић, М. Увод у историју и теорију превођења, Београд: Привредна штампа.

Apel i Mujsken 2005: Appel, R. i P. Muysken. Language Contact and Bilingualism. Amsterdam: Amsterdam University Press.

Beher, Haus i Kranih 2009: Becher V. House J. \& Kranich S. Convergence and divergence of communicative norms through language contact in translation. In: K. Braunmüller and J. House (eds.). Convergence and Divergence in Language Contact Situations. Hamburg: John Benjamins, 125 - 152.

Eko 2006: Eko, U. Otprilike isto: iskustva prevođenja, Zagreb: Algoritam. Filipović 1999: Filipović, J. Varijacije unutar padežnih sistema u različitim tipovima srpskih varijeteta - U prilog jedinstvenoj teoriji jezičkih promena, Zbornik Matice Srpske za filologiju i lingvistiku, 42 (1): 5968.

Filipović 2009: Filipović, J. Moć reči: Ogledi iz kritičke sociolingvistike, Beograd: Zadužbina Andrejević.

Filipović 1986: Filipović, R. Teorija jezika u kontaktu: uvod u lingvistiku jezičnih dodira. Zagreb: Jugoslovenska akademija znanosti i umjetnosti, Školska knjiga.

Haugen 1988: Haugen, E. The Influence of English: A Transatlantic Perspective, In: Folia Linguistica.

Ivir 1985: Ivir, V. Teorija i tehnika prevođenja, Novi Sad: Zavod za izdavanje udžbenika.

Jovanović 2015: Jovanović, A. Osnovi teorije prevođenja, Beograd: Factum izdavaštvo.

Ketford 1965: Catford, J. A Linguistic Theory of Translation, London: Oxford University Press.

Klajn 2003: Clyne, M. Dynamics of Language Contact: English and Immigrant Languages, Cambridge, New York: Cambridge University Press.

Kranih, Beher i Heder 2011: Kranich, S. Becher, V. Höder S. A tentative typology of translation-induced language change. In: S. Kranich, V., Becher, S. Höder, \& J. House, (eds.) Multilingual Discourse Production. Diachronic and Synchronic Perspectives, Amsterdam and 
Philadelphia: John Benjamins. 11-44.

Kristal 2003: Crystal, D. English as a Global Language, Cambridge University Press.

Labov 1972: Labov, W. Language In The Inner City: Studies In The Black English Vernacular, Philadelphia: University of Pennsylvania Press. Labov 2006: Labov, W. The Social Stratification of English in New York City. (2nd ed.). Cambridge: Cambridge University Press.

Matras 2009: Matras, Y. Language Contact, Cambridge: Cambridge University Press.

Meyerhoff 2006: Meyerhoff, M. Introducing Sociolinguistics, London and New York: Routledge.

Mandej 2005: Munday, J. Introducing Translation - Theories and Applications, New York: Routledge.

Milroj i Gordon 2003: Milroy, L. \& Gordon, M. Sociolinguistics: Method and Interpretation. London: Blackwell.

Najda 1964: Nida, E. Toward a Science of Translating, Leiden, Brill.

Prćić 2011: Prćić, T. Engleski u srpskom, Novi Sad: Zmaj.

Radovanović 2015: Radovanović, M. Fazi lingvistika, Izdavačka knjižarnica Zorana Stojanovića: Sremski Karlovci, Novi Sad.

Rajs 2000: Reiss, K. Translation Criticism: The Potentials and Limitations.

Categories and Criteria for Translation Quality Assessment, London:

St. Jerome publishing.

Štajner 1975: Steiner, G. After Babel: Aspects of language and translation, Oxford: Oxford University Press.

Tomason i Kaufman 1988: Thomason, S.G. Kaufman, T. Language Contact, Creolization, and Genetic Linguistics, University of California Press.

Vajnrajh 1968: Weinreich, U. Languages in Contact: Findings and Problems, The Hague: Mouton Publishers.

Venuti 2000: Venuti, L. (ed.), The Translations Studies Reader, London and New York: Routledge. 


\title{
Jelena Simunović Poluga
}

\section{POSSIBILITY OF AN INTERDISCIPLINARY APPROACH IN TRANSLATION RESEARCH}

\begin{abstract}
Summary
The goal of this contribution is to provide a brief overview of a theoretical introduction and terminology which are necessary for researching contact-induced language change. Namely, it was first neccessary to determine a wider theoretical framework by considering aspects of traductology, contact linguistics and sociolinguistics in translation research as well as language change in general, and then to determine a more narrow theoretical framework where we dealt with only translation as a site of contact and contact-induced language change.
\end{abstract}

Key words: language contact and impact, translation as a site of language contact, translation induced language change 